\title{
CEBPB wt Allele
}

National Cancer Institute

\section{Source}

National Cancer Institute. CEBPB wt Allele. NCI Thesaurus. Code C104117.

Human CEBPB wild-type allele is located in the vicinity of $20 q 13.1$ and is approximately 2 $\mathrm{kb}$ in length. This allele, which encodes CCAAT/enhancer-binding protein beta protein, is involved in both the acute-phase reaction and inflammation. 